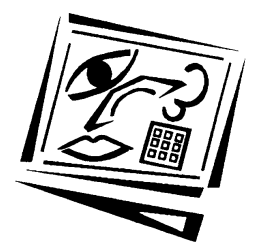

\title{
Collaborative development of an online pharmacy experiential learning database
}

\author{
Susanne Owen \\ University of South Australia \\ Greg Ryan, Jim Woulfe \\ University of Sydney \\ Leigh McKauge \\ University of Queensland \\ Ieva Stupans \\ University of New England
}

\begin{abstract}
Academics preparing students for experiential placements within professional programs require considerable curriculum planning and pedagogical expertise. Communities of practice involving workshops and online processes provide opportunities for collaborative work in developing quality curriculum materials and also in supporting widespread dissemination. The aim of an Australian Learning and Teaching Council funded project was to collaboratively establish an online repository of tasks and other associated resources. These tasks were intended for potential inclusion in the suite of activities that could be required to be completed in a pharmacy experiential clinical placement. An educational template and website were initially created, with over 90 academics and other industry partners subsequently attending a series of workshops to share ideas and develop the online materials. Online surveys regarding the tasks, written feedback concerning workshop processes and interviews were conducted as part of the ongoing evaluation processes to ascertain the effectiveness of the tasks and processes and to inform future directions. Workshops and follow up processes resulted in publication of twenty eight tasks, positive responses to the materials and to the collaborative processes.
\end{abstract}

\section{Introduction}

Experiential placements are a key component in the preparation of students for professional practice. The purpose of experiential placements within preparatory programs includes acquisition of professional knowledge, skills and attitudes; applying and developing classroom learning and theory in work settings; clarifying and determining career directions; utilising generic skills developed at university; establishing workforce contacts; and becoming 'work literate' (which includes the development of professional identity) (Waters, 2001; Orrell, 2004). Placements provide tertiary students with opportunities to carry out relevant activities, in real environments, with actual clients.

Within professional programs, higher education teachers and academics are generally highly skilled in relevant discipline-specific content areas but often require considerable support in utilising a wide range of educational methods to promote 
student learning in the pre-, during, and post- phases of learning and experiential placements. To support academics in developing quality curriculum materials for student placements there is value in material being made available and accessible within online contexts (Fjuk \& Sorensen, 1997). Supplementing the online materials with face to face collaborative development of materials and then disseminating the work within online repositories and other web technologies provides significant additional benefits (Read, Buntine, Crisp, Barrie, George, Kable, Bucat \& Jamie, 2006; Buntine, Read, Barrie, Bucat, Crisp, George, Jamie \& Kable, 2007). Various disciplines have used face to face and online processes to widen the skills of academics beyond traditional lecturing and examination approaches (Owen \& Davis, 2009; Timberlake, 2008).

Results of a national Australian Learning and Teaching Council (ALTC) funded study of university pharmacy school programs in Australia (Owens \& Stupans, 2008) established a need for greater clarity of the goals of placement activities; more deliberate scaffolding of student experiences at the pre-placement, during placement and post-placement stages; and the importance of building student and supervisor skills in reflection and feedback into the learning process.

Based on the recommendations of this earlier work (Owen \& Stupans, 2008), additional ALTC grant funding was secured to establish an online repository of collaboratively developed learning and assessment activities using an educational template and planning model incorporating learning outcomes, criteria for assessment and evaluation processes. The aim of the work was to collaboratively establish an online repository of tasks and other associated resources, using an educationally-sound curriculum template. These tasks were intended for potential inclusion in the suite of activities that could be required to be completed in a pharmacy experiential clinical placement. A collaborative process was used in the development of the tasks to build curriculum planning skills and promote sharing of ideas and practices.

This paper reports on the design, development and evaluation of the experiential learning database and seeks to promote discussion about supporting change and building academic skills within a community of practice framework. This discussion paper focused on collaborative development and publication of website tasks also provides some evidence-based ideas for possible further exploration by other disciplines in their curriculum skill building work among academics who are located across diverse contexts.

\section{Method}

The methodological approach for the pharmacy experiential placement research was contextualised within a community of practice framework involving collaborative workshops and online processes and also operating within an overall action research framework. Action research is regarded as a powerful tool for change and improvement. Basic components of an action research cycle are: planning, action, observation, and reflection. Projects often require several iterations or spirals of this basic cycle and within each phase of the cycle (Cohen, Manion \& Morrison, 2003:227).

The action research process used in building the pharmacy website and collaboratively developing tasks can be contextualised within the notion of communities of practice which is defined by Wenger, McDermott and Snyder as 'groups of people who share a 
concern, a set of problems, or a passion about a topic, and who deepen their knowledge and expertise ... by interacting on an ongoing basis.' (2002: 10). Joint enterprises focused on practical activities and building shared beliefs over an extended timeline, collaboration, creating an identity with the community and taking responsibility for the learning of others and ensuring sustainability are key features (Owen, 2004).

While communities of practice often build professional skills through face to face involvement, benefits for health teams learning within technology-supported communities of practice have been highlighted (Ho, Jarvis-Selinger, Norman, Olatunbosun, Cressman \& Nguyen, 2010). However, research concerning the creation of the Carrick (now ALTC) Exchange, which has supported various disciplines, has acknowledged the problem of widespread lack of engagement of users of online repositories (O'Reilly, Lefoe, Phillip \& Parrish, 2008; Lefoe, Phillip \& O'Reilly, 2009). To prevent this, extensive consultation with end users regarding the development and usability of the repository together with the creation of networks and 'communities of practice' has been recommended (O'Reilly et al., 2008).

Consistent with this advice, the five person project team involved in the development in the pharmacy experiential learning tasks and website used an iterative and collaborative development process that involved a wide range of stakeholders, representing academics, students, practitioners and preceptors, and professional and accrediting organisations and agencies from around Australia. Consultation occurred with over 250 university academics, preceptors, students, hospital and community pharmacists and professional organisation and registration representatives. In particular, the team forged strong links with the Australasian Pharmaceutical Science Association (APSA), the Pharmaceutical Society of Australia (PSA) and the Australian Pharmacy Council (APC).

A six-member project reference group was also established, with members representing the key stakeholder groups. The reference group role was to advise the project team and to provide feedback at key points throughout the project.

The project process involved planning and developing the site activities, monitoring the use, and collecting and evaluating user perspectives of the site, then making changes in response to the evaluation; observing and analysing the outcomes again, and reflecting on the findings. The two key design elements were the development of an educational template and creation of the website, and the planning and facilitation of a series of collaborative workshops at national conferences.

A preliminary workshop was held involving the eleven project team and reference group members in developing the educational template, trialling the workshop process, creating exemplar activities and planning the first full-scale national workshop. During this phase, two existing local websites were examined in detail for features relevant to the project. The Advancing Chemistry by Enhancing Learning in the Laboratory (ACELL) website (Buntine et al., 2007) proved useful for its collaborative, workshop-based development model; and the Technology Supported Learning Database (TSLDB) site for its user-generated approach to website content.

Provision of a collaborative writing and editing space for the development of the experiential learning activities was a high priority for the project team. The Drupal open-source content management system (http://www.drupal.org/) was chosen as 
the platform for the website. This system enables users to contribute content to a website and, subject to the rules configured by the site administrators, allows users to edit other people's contributions. The Drupal platform is modular and highly flexible, allowing real-time changes to the site based on user feedback. This flexibility enabled the creation, editing, storage and dissemination of user-generated learning materials. Users who signed up to the site had access to activities according to their role: academic, preceptor or student. Role-specific evaluation forms provided ongoing evaluation of each learning activity's effectiveness in enhancing student competency, and guide continuing improvement of both the activities and the Pharmacy Experiential Learning Database site as a whole. The design and functionality of the website was implemented by the project's educational designer, in collaboration with an experienced Drupal developer.

At the project workshops and within a national pharmacy education workshop during several consecutive years, over 90 academics and professional/registration board representatives from across all states and territories and most pharmacy schools worked together on a wide range of topics to develop learning and assessment activities using the online educational template.

A list of potential task topics relevant to experiential placements was forwarded to workshop registrants prior to each workshop and attendees selected a topic and brought along related materials from their own institutions. The emphasis was on the creation of new, shared resources to be made publicly available under an international Creative Commons licence (http://creativecommons.org/licenses/). Topics covered varied with each workshop but included introduction to hospital pharmacy, patient counselling in complex situations, scaffolding for clinical placement, and the use of portfolios to promote student reflection on placement experiences. Each topic group was supported by a group leader, with participants sharing materials from their own universities and then working collaboratively in groups of three or four during the workshop to create a new activity using the online template, under the guidance of the members of the project team. Scaffolding strategies developed during the workshops included:

- prompts and guidance for supervisors of students to use during placements, such as questions to highlight further detail the student needs to acquire in relation to various drugs and health care issues and the many subtle points of practice;

- frameworks for guided reflection to support student learning; protocol processes that require students to describe actions undertaken in specific incidents, how they felt about the situation, what they learned from the experience, other areas for improvement, and what they would do in a future situation

After the workshops, follow up occurred through assigned group leaders liaising with other group members to finalise the activities.

A pre-publication checklist was used by the project team as part of the quality assurance processes, with the following key aspects being included:

- Objectives/outcomes are outlined.

- Competencies for the pharmacy profession (PSA) and graduate attributes are identified.

- Sequencing of the learning activity is clear.

- Assessment task is outlined (if applicable). 
- Assessment criteria are linked to objectives/outcomes.

- Language is clear and concise.

- Indication is given of the applicability to students in early or later years of their training.

- Worksheets are attached as appropriate.

Publication and the release of the activity to site users then occurred. A short description was made available to all site visitors and registered site visitors were able to download and use the entire activity.

Reflecting an action research approach and collaborative work underway, three data sources were used at various times to collect evidence and to make changes and inform the next steps. Written surveys at workshops, interviews and an online survey for each task were the data sources used. Table 1 provides details regarding data collection activities which are relevant to this paper.

Table 1: Data collection

\begin{tabular}{|l|c|l|l|l|}
\hline $\begin{array}{c}\text { Data } \\
\text { type }\end{array}$ & $\begin{array}{c}\text { Participant } \\
\text { numbers } \\
\text { involved }\end{array}$ & $\begin{array}{c}\text { Stakeholder group } \\
\text { and event }\end{array}$ & \multicolumn{1}{|c|}{$\begin{array}{c}\text { Data } \\
\text { details }\end{array}$} & $\begin{array}{c}\text { Collation } \\
\text { and analysis }\end{array}$ \\
\hline $\begin{array}{l}\text { Written } \\
\text { survey }\end{array}$ & 16 & $\begin{array}{l}\text { Workshop } \\
\text { participants including } \\
\text { academics, } \\
\text { professional body } \\
\text { representatives }\end{array}$ & $\begin{array}{l}\text { 5 point Likert scale written feedback } \\
\text { re website tasks }\end{array}$ & $\begin{array}{l}\text { Manual } \\
\text { collation } \\
\text { and analysis }\end{array}$ \\
\hline Interviews & 17 & $\begin{array}{l}\text { Project } \\
\text { team/reference group } \\
\text { members, workshop } \\
\text { attendees }\end{array}$ & $\begin{array}{l}\text { Semi structured interviews with } \\
\text { external evaluator re quality and } \\
\text { use of website tasks, usefulness of } \\
\text { collaborative workshop processes, } \\
\text { impact on own practice and on } \\
\text { others }\end{array}$ & $\begin{array}{l}\text { Manual } \\
\text { collation } \\
\text { and analysis }\end{array}$ \\
\hline $\begin{array}{l}\text { Online } \\
\text { survey }\end{array}$ & 24 & Website task users & $\begin{array}{l}\text { 11 questions using a 5 point Likert } \\
\text { scale }\end{array}$ & Electronic \\
\hline
\end{tabular}

Table 1 indicates that one data source utilised involved a five point Likert scale survey (strongly agree, agree, neutral, disagree, strongly disagree) within a workshop concerning the website being easy to use and providing useful information. Free response questions provided additional opportunities for comment.

Secondly, at various times within the two year project, semi-structured interviews were conducted by an external evaluator involving interviews with project team/reference group members and with workshop attendees. Questions asked included those relating to the value of the workshop collaborative processes, usefulness of the published tasks and the website impact on practice and networks.

Thirdly, a survey for each published task was available on the website. This survey involved 11 questions using a five point Likert scale survey questionnaire (strongly agree, agree, neutral, disagree, strongly disagree) regarding aspects such as the relevance of the task to pharmacy programs, clarity and helpfulness of documentation, assessment matching outcomes/matching tasks, learning tasks matching outcomes, the website being easy to use, steps being clear and the website providing useful resources. 


\section{Results}

Findings from the data collection activities are presented in relation to online activities, written surveys at workshops regarding the website activities, and external evaluator interviews regarding the website. Online survey responses regarding individual experiential learning activities are also outlined.

\section{Medicines Review - Authentic Patient}

Learning Outcomes: This activity is designed for advanced level learners. On completion

of the activity, students should be able to:

- elicit a comprehensive medical and medication history

- identify and prioritise actual and potential drug-related problems

- make recommendations regarding optimal management

- communicate effectively and ethically through appropriate verbal, written and visual formats with health and social care professionals with the aim of providing optimal patient care and safety

The activity relates to the Competency Standards for Pharmacists in Australia:

Domain 1: professional and ethical practice

Domain 2: communication, collaboration and self-management

Domain 7: promote and contribute to optimal use of medicines

Domain 8: critical analysis, research and education

It also addresses Graduate Attributes/Qualities Body of knowledge, Analysis and problem solving and Communication

Description of the activity: The activity takes place in three stages.

Stage One:

Patient is identified.

Student researches required information and prepares relevant questions.

Patient consent obtained for review process.

Student attends and where possible conducts patient interview.

Stage Two:

Results and key findings summarised.

Written report

- letter to the GP

- recommendations and supporting evidence

Oral case defence to other students, preceptor and GP

Stage Three:

Feedback provided by

- Preceptor

- GP

- peers

- university staff

Background and University pre-placement responsibility

Prior to interviewing the patient the following should be considered:

- Confidentiality forms

- Patient consent (written).

- Student orientation to the experiental environment.

Patient identification may be undertaken by preceptor or student.

Student role, learning activities and responsibilities

Please see the attachment

Student Role Attachments: HMRstudent_preparation.pdf

Assessment: See the following attachments for a suggested marking scheme Assessment Attachments: HMRMarkingGuide.pdf

Figure 1: Medicines review authentic patient example 


\section{Online activities}

During the two year project timeframe, over 90 pharmacy academics and professionals enrolled on the Pharmacy Learning database as contributors, editors and users. Core features of the template used in the collaborative development of tasks included a statement of learning outcomes mapped to the profession's competencies, description of the activity, university responsibilities, student role/responsibilities, preceptor role and assessment items and marking guides.

Figure 1 (above) provides an example of an activity created using the online template and collaborative professional learning process, with accessibility through the website at http:/ / pharmacylearning.edu.au/

Table 2: Smoking cessation assessment rubric

\begin{tabular}{|c|c|c|c|c|}
\hline & Exceptional (3) & Acceptable (2) & Marginal (1) & Unacceptable $(0)$ \\
\hline $\begin{array}{l}\text { Identification } \\
\text { of pharmaco- } \\
\text { logical } \\
\text { smoking } \\
\text { cessation } \\
\text { treatments }\end{array}$ & $\begin{array}{l}\text { Report comprehen- } \\
\text { sively identifies } \\
\text { smoking cessation } \\
\text { treatments, iden- } \\
\text { tifies appropriate } \\
\text { clients for each }\end{array}$ & $\begin{array}{l}\text { Report comprehensiv- } \\
\text { ely identifies smoking } \\
\text { cessation treatments, } \\
\text { incomplete identif- } \\
\text { ication of appropriate } \\
\text { clients for each }\end{array}$ & $\begin{array}{l}\text { Report identifies } \\
\text { smoking cessation } \\
\text { treatments, how- } \\
\text { ever identification } \\
\text { is not comprehen- } \\
\text { sive }\end{array}$ & $\begin{array}{l}\text { Report identifies } \\
\text { smoking cessa- } \\
\text { tion treatments, } \\
\text { significant omis- } \\
\text { sions evident }\end{array}$ \\
\hline $\begin{array}{l}\text { Identification } \\
\text { of non phar- } \\
\text { macological } \\
\text { smoking } \\
\text { cessation } \\
\text { supports }\end{array}$ & $\begin{array}{l}\text { Report comprehen- } \\
\text { sively identifies non } \\
\text { pharmacological } \\
\text { smoking cessation } \\
\text { treatments, } \\
\text { identifies approp- } \\
\text { riate clients for each }\end{array}$ & $\begin{array}{l}\text { Report comprehensiv- } \\
\text { ely identifies non } \\
\text { pharmacological } \\
\text { smoking cessation } \\
\text { treatments, incompl- } \\
\text { ete identification of } \\
\text { appropriate clients for } \\
\text { each }\end{array}$ & $\begin{array}{l}\text { Report identifies } \\
\text { non pharmacolog- } \\
\text { ical smoking cess- } \\
\text { ation treatments, } \\
\text { however identific- } \\
\text { ation is not } \\
\text { comprehensive }\end{array}$ & $\begin{array}{l}\text { Report identifies } \\
\text { non pharmacol- } \\
\text { ogical smoking } \\
\text { cessation treat- } \\
\text { ments, significant } \\
\text { omissions } \\
\text { evident }\end{array}$ \\
\hline $\begin{array}{l}\text { Description } \\
\text { of preceptor } \\
\text { making } \\
\text { recomm- } \\
\text { endations }\end{array}$ & $\begin{array}{l}\text { Careful observation } \\
\text { and interpretation } \\
\text { of process. Points } \\
\text { for clarification } \\
\text { identified }\end{array}$ & $\begin{array}{l}\text { Careful observation } \\
\text { and interpretation of } \\
\text { process }\end{array}$ & $\begin{array}{l}\text { Careful observ- } \\
\text { ation but interp- } \\
\text { retation of process } \\
\text { not attended to }\end{array}$ & $\begin{array}{l}\text { Poor observation, } \\
\text { no interpretation } \\
\text { of process }\end{array}$ \\
\hline $\begin{array}{l}\text { Self audit of } \\
\text { performance } \\
\text { regarding } \\
\text { recommend- } \\
\text { ations to } \\
\text { client }\end{array}$ & $\begin{array}{l}\text { Completion of self } \\
\text { audit and self } \\
\text { assessment of } \\
\text { process clearly } \\
\text { linked }\end{array}$ & $\begin{array}{l}\text { Completion of self } \\
\text { audit and self } \\
\text { assessment of process } \\
\text { linked superficially }\end{array}$ & $\begin{array}{l}\text { Completion of self } \\
\text { audit and self } \\
\text { assessment of } \\
\text { process poorly } \\
\text { linked }\end{array}$ & $\begin{array}{l}\text { Self assessment } \\
\text { not performed }\end{array}$ \\
\hline $\begin{array}{l}\text { Presentation } \\
\text { of report }\end{array}$ & $\begin{array}{l}\text { Sequencing of ideas } \\
\text { makes the presen- } \\
\text { tation easy to follow }\end{array}$ & $\begin{array}{l}\text { Sequencing of ideas } \\
\text { mostly appropriate in } \\
\text { making the presen- } \\
\text { tation easy to follow }\end{array}$ & $\begin{array}{l}\text { Needs to improve } \\
\text { sequencing of } \\
\text { ideas in order to } \\
\text { make the present- } \\
\text { ation easy to } \\
\text { follow }\end{array}$ & $\begin{array}{l}\text { Structure, lack of } \\
\text { transitions and / } \\
\text { or sequencing of } \\
\text { ideas make } \\
\text { understanding } \\
\text { difficult }\end{array}$ \\
\hline $\begin{array}{l}\text { Reflection } \\
\text { regarding } \\
\text { self develop- } \\
\text { ment around } \\
\text { smoking } \\
\text { cessation }\end{array}$ & $\begin{array}{l}\text { Reflection and self } \\
\text { development plan } \\
\text { for are clearly } \\
\text { communicated }\end{array}$ & $\begin{array}{l}\text { Reflection and self } \\
\text { development plan for } \\
\text { are mostly clearly } \\
\text { communicated }\end{array}$ & $\begin{array}{l}\text { Reflection mostly } \\
\text { clearly commun- } \\
\text { icated }\end{array}$ & $\begin{array}{l}\text { Record of process } \\
\text { rather than } \\
\text { reflection }\end{array}$ \\
\hline
\end{tabular}


Consistent with the template for all online activities, key features indicated are the statement of learning outcomes (including links to the relevant domains of the profession's competencies and university graduate attributes); responsibilities of university and students and assessment materials including rubrics where applicable. For example, the assessment rubric for another activity, the Smoking Cessation Awareness in a Community Pharmacy is indicated in Table 2 (above).

The website exceeded its initial target for published activities and eventually comprised 28 published activities. These relate to patient counselling, researching the community, creating an experiential portfolio, smoking cessation awareness, taking a patient history and writing case reports, reflection, dispensing, compounding, interprofessional learning, over the counter products and medication management review processes. Activities have been mapped to the updated professional competencies, the Pharmaceutical Society of Australia's Competency Standards for Pharmacists in Australia (PSA, 2010).

\section{Written surveys at workshops regarding the activities}

Regarding the website, 16 responses were received from workshop participants at one event. Eighty percent of written survey respondents strongly agreed (and 20\% agreed) that the website was easy to use. Thirty-seven percent strongly agreed and $63 \%$ agreed about its usefulness, commenting specifically on aspects such as 'usefulness of links to attributes and competencies' and provision of 'dispensing info (information) for my course'.

Some specific issues raised in the written feedback in relation to the website were about improving the 'save' function to support the collaborative processes of creating the tasks and seeking student and practitioner feedback about the website tasks.

\section{External evaluator interviews regarding website}

External evaluator interviews with seventeen project team members, reference group or workshop attendees on various occasions throughout the project indicated that there were varying degrees to which the website had been used. It was also indicated that wider use was likely in the future as more activities became available and as more links to other resources were made (seventeen activity tasks available at the time of the interviews in the latter stages of the project).

An example comment of this viewpoint, as expressed by an academic who was a member of the project team, is:

I've used it ... it contains useful info: work is attributed - it's a truly shared resource. I've really appreciated the collegiate, generous, goal-oriented approach, rare in academic circles. It's not every day you're redesigning a course - that's when you'd use it. My colleagues are using it and I point people towards it. Not a day-to-day log on. It's a resource so I don't need to reinvent the wheel.

There was also a sense that as more resources become available on the website, it will become more widely used, including having more activities and links to journals, or perhaps a more interactive area to encourage sharing of ideas. For example:

The only shame is that with the database there are only 11 activities [at that time].

Good if each uni could agree to put up new activities every year. But the time taken to 
put it up and get it right is time we don't have. Maybe if each uni applied for funding to contribute to the database it would work.

Regarding individual activities there were many positive comments from academics interviewed who were involved in the workshops (non-project team members). Comments included:

Definitely: the material on individual reflection on a group assignment has been used this semester. I was undecided as to how to do this before but I was shown a 'working example'.

Changes to the description of reflection as an educative activity - used wording recommended by a colleague; wording was more 'student' orientated in the description.

I set an exam question about reflection where the criteria for the answer were refined after a discussion at a workshop.

I reworked practice questions (re non-prescription requests) given the discussion by community pharmacists re current practice.

A general comment about the value of the website was:

I've shifted across to using competencies in both the placement workbook and 1st year portfolio to explain why we do things. The teaching team has also gone back to see where the skills development is, and now have a progression going through the four years. The concepts of scaffolding and skills development have come to the fore; also that the uni is a safe environment in which to test skills - this is linked to scaffolding. I've introduced a new style of testing in exams, based on prac work. The formative tools used in the portfolio are also used in exams, so that the students are used to what is expected.

\section{Online survey feedback regarding individual activities}

Results from twenty-four respondents providing online survey feedback regarding various online repository activities of their choice indicated essentially positive responses (although not all questions were answered by each respondent). Figure 2 provides the collated results (grouping strongly agree/agree responses and also disagree/strongly disagree results). The figure shows positive responses regarding website activities being essentially relevant to needs $(96 \%)$, activity documentation being clear (92\%), helpfulness of the documentation $(88 \%)$, and learning activities matching outcomes $(90 \%)$. In relation to other aspects, results were assessment matching outcomes $(71 \%)$, assessment matching tasks $(92 \%)$, the website being easy to use $(80 \%)$, steps being clear $(81 \%)$ and providing useful resources $(83 \%)$.

Seventy seven percent of all respondents had actually used the activity which they were commenting on, with or without modifications. Specific comments about the 'learning to be reflective' activity were: 'Being involved in creating these activities is helpful in updating and thinking about what we expect students to do on placement'; 'Very relevant. I like this and I wish I had known of its existence sooner. Are we able to use this resource?'

Broader comments about the website tasks generally included:

The range of topics are all relevant to modern pharmacy.

I really support the repository concept. (I) have contributed and have used pieces of it in developing my experiential learning program. 
Perhaps need to structure a space for others to contribute how they may have modified the activity to suit their purposes so that others can read and get ideas.

... helpful in updating and thinking about what we expect students to do on placement.

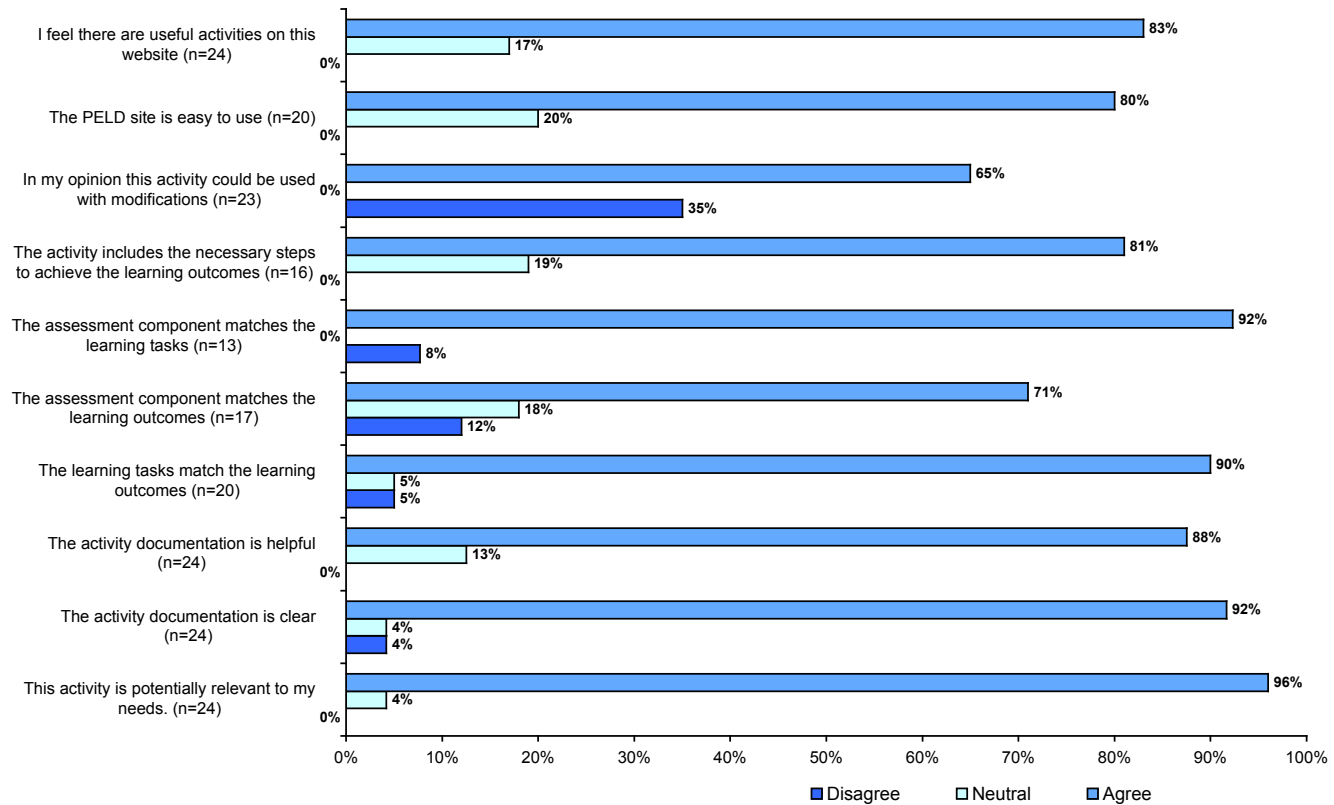

Figure 2: Online survey results regarding individual activities

\section{Discussion}

A series of collaborative pharmacy experiential placement workshops was held linked to the development of online repository tasks, using an action research approach and interviews and surveys. Participants gave positive responses to the collaborative process, the website concept and to the website tasks published. Reflecting the action research approach, the use of an iterative development process proved useful for successful project completion. Workshops held over several years resulted in not only increasing numbers of published activities, but also interview and survey feedback that guided incremental improvements to the website, including its navigability and comprehensiveness.

Furthermore, evidence from surveys and interviews indicated that the website was valued for helping academics in the design and delivery of various tasks relevant for pharmacy experiential learning programs. Consistent with various research findings (Bennett, Agostinho, Lockyer, Harper \& Lukasiak, 2006; O’Reilly et al., 2008), the value of providing software tools which model expert practice and scaffolding to support university teachers in developing pedagogically-sound learning materials was evident. There is also some evidence of some aspects of a community of practice beginning to emerge through the face to face collaborative workshops, and online creation and dissemination of tasks. Defying some trends towards inter-university competitiveness, the workshops to develop the curriculum tasks were clearly focused 
and very practical and collaborative in nature. Reflecting the previously outlined communities of practice research (Wenger et al., 2002; Owen, 2004), many workshop participants brought along materials from their own university programs as a starting point and considerable group discussion and sharing occurred as a new task was developed using the online curriculum planning template. Many participants also attended several workshops over several years and used or modified the online resources published.

However, while some elements were evident, aspects characterising more mature and deeply committed communities of practice such as team members building their sense of identity with others or taking responsibility for the learning of others, were less embedded features. In contrast to the commitment that participants gave to the collaborative development of the activities during the workshops, staying committed to the process of completing and refining their activities to a standard ready for publication seemed difficult to achieve within busy work schedules. While the workshops were highly valued and tasks were eventually published and used, it was difficult to gain a real sense of identity and commitment for the learning of others and so the building of a community of practice was only partially achieved. Given Owen's (2005) work on communities of practice being self-generating but also gaining sustainability through leadership nurturing and support, it may be that a longer timeframe than this two year project is needed. Further funding from an additional related project using the same website and involving generation of other activities through workshop participation by all Australian and New Zealand pharmacy schools may possibly build further commitment and sustainability of the community of practice in future years.

The important place of websites in fostering sustainability is consistent with Laurillard's (2008) research in which she emphasises technology-enhanced learning as a tool for pedagogical innovation, including curriculum skill building and providing the means for articulating and disseminating ideas and materials.

While a limitation of this current project is the small scale nature of data collections, there is some evidence that the dissemination of materials developed through the website has provided some degree of sustainability which can be built on in future project work.

\section{Summary}

Overall, the project produced a valuable online resource for pharmacy educators and students in the broadest sense, with the projectr website being renamed Pharmacy Learning. The design of the online activity template is based on sound pedagogical principles and as such will be of use to other disciplines that are seeking to improve the planning, implementation and evaluation of experiential learning activities. There seems to be sufficient evidence outlined in this paper for further exploration by other disciplines in regard to the benefits for academic learning built across diverse contexts through collaborative processes, with support and sustainability enhanced through the use of website processes. 


\section{Acknowledgments}

Support for this work has been provided by the Australian Learning and Teaching Council, an initiative of the Australian Government Department of Education, Employment and Workplace Relations.

\section{References}

Bennett, S., Agostinho, S., Lockyer, L., Harper, B. \& Lukasiak, J. (2006). Supporting university teachers create pedagogically-sound learning environments using learning designs and learning objects. IADIS International Journal on WWW/Internet, 4(1), 16-26. http:/ / www.iadisportal.org/digital-library/supporting-university-teachers-createpedagogically-sound-learning-environments-using-learning-designs-and-learning-objects

Buntine, M. A., Read, J. R., Barrie, S. C., Bucat, R. B., Crisp, G. T., George, A. V., Jamie, I. M. \& Kable, S. H. (2007). Advancing chemistry by enhancing learning in the laboratory (ACELL): A model for providing professional and personal development and facilitating improved student laboratory learning outcomes. Chemistry Education Research E Practice, 8(2), 232-254. http: / / www.asell.org/ site/document.cfm?doc_id=441

Cohen, L., Manion, L. \& Morrison, K. (2003). Research methods in education. 5th edition. London: Routledge Falmer.

Fjuk, A. \& Sorensen, E. K. (1997). Drama as a metaphor for the design of situated, distributed collaborative learning. European Journal of Open, Distance and E-Learning, 1997. http: / / www.eurodl.org/ materials / contrib/1997 / fjuk/ fjuk.html

Ho, K., Jarvis-Selinger, S., Norman, C. D., Li. L. C., Olatunbosun, T., Cressman, C. \& Nguyen, A. (2010). Electronic communities of practice. Journal of Continuing Education in the Health Professions, 30(2), 139-143. http:/ / www.jcehp.com/vol30/3002_ho.asp

Laurillard, D. (2008). Technology enhanced learning as a tool for pedagogical innovation. Journal of Philosophy of Education, 42(3-4), 521-533. http:/ / dx.doi.org/10.1111/j.14679752.2008.00658.x

Lefoe, G., Philip, R. \& O'Reilly, M. (2009). Developing quality resources for teaching and learning: A peer review model for the ALTC Exchange in Australia. Australasian Journal of Educational Technology, 25(1), 45-59. http: / / www.ascilite.org.au/ajet/ajet25/lefoe.html

Orrell, J. (2004). Work integrated learning programs: Management and educational quality. Proceedings of the Australian University Quality Forum 2004. http: / / tls.vu.edu.au/vucollege/LiWC/resources/Orrell.pdf [Viewed 14 October 2010].

O’Reilly, M., Lefoe, G., Philip, R. \& Parrish, D. (2008) The Carrick Exchange for Higher Education: Design factors for user engagement. ED-MEDIA World Conference on Educational Multimedia, Hypermedia and Telecommunications 2008, Vienna, Austria, 30 June-4 July 2008. http:/ / ro.uow.edu.au/asdpapers/91

Owen, S. (2004). Situativity theory and emerging trends in teacher professional development. In Proceedings AARE Conference 2004. http:/ / www.aare.edu.au/04pap/owe04331.pdf

Owen, S. (2005). Emerging trends in teacher professional development within a career continuum. Doctoral thesis. Adelaide: University of South Australia.

Owen, S. \& Stupans, I. (2008). Pharmacy Learning Resource Database: Practical resources for Pharmacy teachers, supervisors and students. [viewed 29 Sep 2011]. http:// pharmacylearning.edu.au/ 
Owen, S. \& Davis, G. (2009). Learning and teaching in the discipline of law: Achieving and sustaining excellence in a changed and changing environment. [viewed $11 \mathrm{Feb} 2010$ ]. http: / / www.cald.asn.au/docs/altc_LawReport.pdf

Pharmaceutical Society of Australia (PSA) (2010). National competency standards for pharmacists. Canberra: PSA. http:/ / www.psa.org.au/ site.php?id=6783

Read, J., Buntine, M., Crisp, G., Barrie, S., George, A., Kable, S., Bucat, R. \& Jamie, I. (2006). The ACELL project: Student participation, professional development and improving laboratory learning. UniServe Science Assessment Symposium Proceedings. http: / / www.asell.org/global/ docs/readbuntinecrispbarriegeorgekablebucatjamie(2006)_uniserve_p113.pdf

Technology Supported Learning Database (TSLDB). [viewed 12 Dec 2010] http://aragorn.scca.ecu.edu.au/tsldb/

Timberlake, T. (2008). Rationale, restrictions and responses: Online academic development to promote a community of practice. In Hello! Where are you in the landscape of educational technology? Proceedings ascilite Melbourne 2008.

http: / / www.ascilite.org.au/conferences/melbourne08/ procs/timberlake.pdf

Waters, B. (2001). Radical action for radical plans. British Journal of Occupational Therapy, 64(ii), 577-578. http: / / openurl.ingenta.com / content?genre=article\&issn=0308$0226 \&$ volume $=64 \&$ issue $=11 \&$ spage $=577 \&$ epage $=578$

Wenger, E., McDermott, R. \& Snyder, W. M. (2002). Cultivating communities of practice: A guide to managing knowledge. Boston: Harvard Business School Press.

Authors: Susanne Owen, Division of Education, Arts and Social Sciences

University of South Australia. Email: Susanne.Owen@unisa.edu.au

Greg Ryan, Faculty of Pharmacy, The University of Sydney

Jim Woulfe, Sydney e-Learning, The University of Sydney

Leigh McKauge, School of Pharmacy, University of Queensland

Email: 1.mckauge@pharmacy.uq.edu.au

Ieva Stupans, School of Science and Technology, University of New England

Email: ieva.stupans@une.edu.au

Please cite as: Owen, S., Ryan, G., Woulfe, J., McKauge, L. \& Stupans, I. (2011).

Collaborative development of an online pharmacy experiential learning database.

Australasian Journal of Educational Technology, 27(7), 1069-1081.

http:/ / www.ascilite.org.au/ajet/ajet27/owen.html 